\title{
Zhuang Language
}

National Cancer Institute

\section{Source}

National Cancer Institute. Zhuang Language. NCI Thesaurus. Code C154208.

Any of more than a dozen Tai languages spoken by the Zhuang people of southern China in the province of Guangxi and adjacent parts of Yunnan and Guang dong. 